\title{
Ensuring Uniformity of Measurements of Absorbed Doses of Intensive Photon and Electron Radiation in Radiation Technologies
}

\author{
V. V. Generalova, A. A. Gromov, O. I. Kovalenko \\ Research Department of Metrology of Ionizing Radiation, Russian Metrological Institute of Technical Physics \\ and Radio Ingineering (VNIIFTRI), Mendeleevo Moscow Region, Russia \\ Email: koi@vniiftri.ru
}

Received 7 July 2015; accepted 19 August 2015; published 26 August 2015

\begin{abstract}
Ensuring reliability and traceability of the unit of absorbed dose of intense photon and electron radiation, used in radiation technologies in industry, is based on the creation of a system of sample measures and methods of transmission with minimal loss of dimensional accuracy of the unit of absorbed dose from the sample tools to working dosimeters and is a necessary basis of yield growth, of increase of labour productivity and the introduction of innovative products. The measuring capabilities of the State primary special standard of power unit of absorbed dose of intensity photon, electron and beta radiation for radiation technologies and of the standards of the absorbed dose of photon and electron radiation, used for radiation monitoring of radiation processes.
\end{abstract}

\section{Keywords}

Radiation Technology, Absorbed Dose, Ensuring Uniformity of Measurements, Certified Reference Material

Radiation technologies are world widely used (are widely used in international practice) in various branches of industry and science. Among the problems (aims) of radiation technologies, which are solved using photon and electron radiation of high-intensity, are [1] [2]:

1. Sterilization of medical items and processing components for pharmaceuticals in medical and pharmaceutical industries.

2. Change in characteristics of the polymers in the chemical industry.

3. Processing agricultural and food products to extend shelf life in agriculture and the food industry.

4. Valuation of the radio resistance of materials in the electronics industry.

5. Cold radiowave cracking of oil in the petrochemical industry.

6. Processing heat-shrinkage tubings in construction.

How to cite this paper: Generalova, V.V., Gromov, A.A. and Kovalenko, O.I. (2015) Ensuring Uniformity of Measurements of Absorbed Doses of Intensive Photon and Electron Radiation in Radiation Technologies. Journal of Applied Mathematics and Physics, 3, 942-946. http://dx.doi.org/10.4236/jamp.2015.38115 
7. Purification of sewage and decontamination of contaminations in the environment.

A measure of radiation effect in radiation technology, which characterizes the effectiveness of interaction of ionizing radiation with the matter, is the absorbed dose, that is a characteristic, which considers the parameters of the radiation field and features of irradiated objects. The quality of products depends on the accuracy of the determination of this value, as well as the economic efficiency of the technological process. This raises the problem of methodical ensuring among the cardinal problems for the successful development of radiation technology in general.

The absorbed dose of the irradiated objects is needed to be measured with rather high accuracy. Inaccuracy of its determining in most cases should not exceed $(10-12) \%$, in individual cases- $(7-10) \%$ at confidence probability of 0.95 . The absorbed dose must be determined in substances with various chemical composition and state of matter, which are irradiated stationary and in dynamic conditions, in mixing conditions and in the flow. To ensure the reliability of such measurements are required dosimeter, which don't introduce distortions in the field of ionizing radiation, that is chemical composition and effective atomic number are close to the irradiated objects. These requirements meet different types of chemical dosimeters of single-use (liquid, gaseous, solid), based on radiation damages caused by the power transfer of ionizing radiation of dosimetry system [3] [4]. The mechanism of radiation-chemical effects determines the dosimetric and operation characteristics, the limits of adaptability and the field of utilization of a particular dosimetry system.

One of the most urgent tasks of technological dosimetry is the development of standardized tools and methods of direct gaging of large doses, used for controlling radio-technological processes, as well as the creation of a complex of sample measures to ensure the high-precision calibration of dosimeters of photon and electron radiation from the range of $10^{2}$ to $10^{6} \mathrm{~Gy}$.

Creating a system of sample measures and methods of transmission with minimal loss of dimensional accuracy of the unit of absorbed dose from the sample tools to working dosimeters ensures the unity and the accuracy of the measurements of this quantity in progressive branch of chemical technology-in radiation-chemical technology. Centralized and complex solution of these problems is of great industrial importance, since it enables to obtain materials with unique qualities, it is aimed at reducing the cost of radiation-modified products, saves the chemical feedstock, increases the activity factor of radiation of nuclear-fueled plants.

Ensuring traceability of absorbed doses of intense photon and electron radiation, used in radiation technologies in industry, is a necessary basis of yield growth, of increase of labour productivity and the introduction of innovative products.

Modern requirements in measurements of absorbed doses in radiation technologies are presented below (Table 1).

In the measuring area of intensive photon, electron and beta radiation in the Russian Federation is currently functioning the State primary special standard of power unit of absorbed dose of intensity photon, electron and beta radiation for radiation technologies GET 209-2014. The standard provides the following measuring capabilities (Table 2).

In the world practice, there is a system of controlling the results of irradiation, implying the analysis of potential hazards in some critical points. For this purposes, two points are marked out in the technological process, at which it is necessary to dissect microorganisms and insects in order to ensure absolutely high quality production at the output of the technological process. At these points, it is advisable to carry out irradiation [5].

For radiation monitoring of radiation processes certified reference materials are created and now producing. Certified reference materials of the absorbed dose of photon and electron radiation are intended for measuring the absorbed dose of photon and electron radiation in water during radiation monitoring at radiation plants with radioisotope sources and electron accelerators.

Table 1. Modern requirements in measurements of absorbed doses in radiation technologies.

\begin{tabular}{cc}
\hline Task & Regulated borders of absorbed doses’ values, kGy \\
\hline $\begin{array}{c}\text { Radiation processing of foodstuff in the food industry } \\
\text { Sterilization of medical items in the medical industry } \\
\begin{array}{l}\text { Modification of polymers and other materials } \\
\text { in the chemical and petrochemical industries }\end{array}\end{array}$ & $0.1-30$ \\
\hline
\end{tabular}


Table 2. Measuring capabilities of State primary special standard of power unit of absorbed dose of intensity photon, electron and beta radiation for radiation technologies GET 209-2014.

\begin{tabular}{|c|c|c|c|c|c|}
\hline $\mathrm{N}$ & $\begin{array}{c}\text { Measurand } \\
\text { (measurable value) }\end{array}$ & Object of measuring & Method & Measuring range & Uncertainty \\
\hline 1 & $\begin{array}{l}\text { Absorbed dose } \\
\text { rate to water }\end{array}$ & $\begin{array}{l}\text { Calibrated field from } \\
\text { linear accelerator }\end{array}$ & $\begin{array}{c}\text { Measurements } \\
\text { with chemical dosimeters }\end{array}$ & $1 \times 10^{2} \ldots 1 \times 10^{5} \mathrm{~Gy} \cdot \mathrm{s}^{-1}$ & $2.5 \%$ \\
\hline 2 & $\begin{array}{l}\text { Absorbed dose } \\
\text { to water }\end{array}$ & Chemical dosimeters & $\begin{array}{l}\text { Irradiation in calibrated field from } \\
\text { linear accelerator (high level) }\end{array}$ & $1 \times 10^{1} \ldots 1 \times 10^{6} \mathrm{~Gy}$ & $2.5 \%$ \\
\hline 3 & $\begin{array}{l}\text { Absorbed dose } \\
\text { rate to water }\end{array}$ & $\begin{array}{c}\text { Calibrated field from } \\
\text { Sr-90/Y-90 } \\
\text { radionuclide sources }\end{array}$ & $\begin{array}{l}\text { Measurements with chemical } \\
\text { dosimeters }\end{array}$ & $3 \times 10^{-1} \ldots 1 \times 10^{2} \mathrm{~Gy} \cdot \mathrm{s}^{-1}$ & $2.5 \%$ \\
\hline 4 & $\begin{array}{l}\text { Absorbed dose } \\
\text { to water }\end{array}$ & Chemical dosimeters & $\begin{array}{l}\text { Irradiation in calibrated field } \\
\text { from Co-60 radionuclide } \\
\text { sources (high level) }\end{array}$ & $1 \times 10^{1} \ldots 1 \times 10^{6} \mathrm{~Gy}$ & $1.2 \%$ \\
\hline 5 & $\begin{array}{l}\text { Absorbed dose } \\
\text { to water }\end{array}$ & Chemical dosimeters & $\begin{array}{l}\text { Irradiation in calibrated field } \\
\text { from Cs-137 radionuclide } \\
\text { sources (high level) }\end{array}$ & $1 \times 10^{1} \ldots 1 \times 10^{6} \mathrm{~Gy}$ & $1.2 \%$ \\
\hline 6 & $\begin{array}{l}\text { Absorbed dose } \\
\text { to graphite }\end{array}$ & Chemical dosimeters & $\begin{array}{l}\text { Irradiation in calibrated field } \\
\text { from Co-60 radionuclide } \\
\text { sources (high level) }\end{array}$ & $1 \times 10^{1} \ldots 1 \times 10^{6} \mathrm{~Gy}$ & $1.2 \%$ \\
\hline 7 & $\begin{array}{l}\text { Absorbed dose } \\
\text { to graphite }\end{array}$ & Chemical dosimeters & $\begin{array}{l}\text { Irradiation in calibrated field } \\
\text { from Cs-137 radionuclide } \\
\text { sources (high level) }\end{array}$ & $1 \times 10^{1} \ldots 1 \times 10^{6} \mathrm{~Gy}$ & $1.2 \%$ \\
\hline 8 & $\begin{array}{l}\text { Absorbed dose to } \\
\text { aluminium }\end{array}$ & Chemical dosimeters & $\begin{array}{c}\text { Irradiation in calibrated field } \\
\text { from Sr-90/Y-90 radionuclide } \\
\text { sources (high level) }\end{array}$ & $1 \times 10^{1} \ldots 1 \times 10^{6} \mathrm{~Gy}$ & $1.5 \%$ \\
\hline 9 & $\begin{array}{l}\text { Absorbed dose } \\
\text { to graphite }\end{array}$ & Chemical dosimeters & $\begin{array}{c}\text { Irradiation in calibrated field } \\
\text { from Sr-90/Y-90 radionuclide } \\
\text { sources (high level) }\end{array}$ & $1 \times 10^{1} \ldots 1 \times 10^{6} \mathrm{~Gy}$ & $1.5 \%$ \\
\hline 10 & $\begin{array}{l}\text { Absorbed dose } \\
\text { to PMMA }\end{array}$ & Chemical dosimeters & $\begin{array}{c}\text { Irradiation in calibrated field } \\
\text { from Sr-90/Y-90 radionuclide } \\
\text { sources (high level) }\end{array}$ & $1 \times 10^{1} \ldots 1 \times 10^{6} \mathrm{~Gy}$ & $2.5 \%$ \\
\hline 11 & $\begin{array}{l}\text { Absorbed dose to } \\
\text { polystyrene }\end{array}$ & Chemical dosimeters & $\begin{array}{c}\text { Irradiation in calibrated field } \\
\text { from Sr-90/Y-90 radionuclide } \\
\text { sources (high level) }\end{array}$ & $1 \times 10^{1} \ldots 1 \times 10^{6} \mathrm{~Gy}$ & $2.5 \%$ \\
\hline 12 & $\begin{array}{l}\text { Absorbed dose to } \\
\text { polycarbonate }\end{array}$ & Chemical dosimeters & $\begin{array}{c}\text { Irradiation in calibrated field } \\
\text { from Sr-90/Y-90 radionuclide } \\
\text { sources (high level) }\end{array}$ & $1 \times 10^{1} \ldots 1 \times 10^{6} \mathrm{~Gy}$ & $2.5 \%$ \\
\hline 13 & $\begin{array}{l}\text { Absorbed dose to } \\
\text { polystyrene }\end{array}$ & Chemical dosimeters & $\begin{array}{l}\text { Irradiation in calibrated field } \\
\text { from Co-60 radionuclide } \\
\text { sources (high level) }\end{array}$ & $1 \times 10^{1} \ldots 1 \times 10^{6} \mathrm{~Gy}$ & $1.2 \%$ \\
\hline 14 & $\begin{array}{l}\text { Absorbed dose to } \\
\text { polystyrene }\end{array}$ & Chemical dosimeters & $\begin{array}{l}\text { Irradiation in calibrated field } \\
\text { from Cs-137 radionuclide } \\
\text { sources (high level) }\end{array}$ & $1 \times 10^{1} \ldots 1 \times 10^{6} \mathrm{~Gy}$ & $1.2 \%$ \\
\hline
\end{tabular}

Certified reference materials are:

1) single-use polymer films, size 10 - $12 \times 30$ - 35 mm, 3 - 6 units (a unit CO), vacuum-packed in polyethylene laminated paper;

2) recoverable glass plane-parallel plates of silicious glass, activated with nickel, manufactured by TU 28 - 30. Synthetic composition of glass in mass percent: $\mathrm{SiO}_{2}-70.4 ; \mathrm{MgO}-1.0 ; \mathrm{ZnO}-3.0 ; \mathrm{CaO}-5.0 ; \mathrm{As}_{2} \mathrm{O}_{3}-0.2$; $\mathrm{Na}_{2} \mathrm{O}-15.0 ; \mathrm{K}_{2} \mathrm{O}-5.0$ (3\% of which is introducted in the form of nitre); $\mathrm{NiO}-0.4 ; \mathrm{NaCl}-3.0 ; \mathrm{Fe}_{2} \mathrm{O}_{3}-$ not more than 0.005 .

Measuring of the optical density of the films and the glasses is held at the spectrophotometer Specord M40, relative to the key sample.

Metrological and technical characteristics of certified reference materials of absorbed dose of photon and electron radiation are presented on the Table 3. 
Table 3. Metrological and technical characteristics of the state certified reference materials.

\begin{tabular}{|c|c|c|c|c|c|}
\hline \multirow[b]{2}{*}{ Characteristics } & \multicolumn{5}{|c|}{ Type of certified reference material } \\
\hline & $\begin{array}{c}\mathrm{CO} \\
\text { ПД(Ф)Р-5/50 }\end{array}$ & $\begin{array}{c}\mathrm{CO} \\
\text { ПД(Ф)Э-5/50 }\end{array}$ & $\begin{array}{c}\mathrm{CO} \\
\text { ПД(Ф)Р-30/200 }\end{array}$ & $\begin{array}{c}\mathrm{CO} \\
\text { ПД(Э)-1/10 }\end{array}$ & $\begin{array}{c}\text { СО ПД } \\
\text { (ДТС)-0,05/10 }\end{array}$ \\
\hline $\begin{array}{l}\text { Number of registry, } \\
\text { certificate number, expiration date }\end{array}$ & $\begin{array}{c}\text { ГСО } 7865-2000, \\
\text { № }{ }^{\circ} 1903, \\
18.01 .2016\end{array}$ & $\begin{array}{c}\text { ГCO 7904-2001, } \\
\text { № }{ }^{\circ} 2069, \\
16.09 .2016\end{array}$ & $\begin{array}{c}\text { ГСО 7903-2001, } \\
\text { № } 2068, \\
16.09 .2016\end{array}$ & $\begin{array}{c}\text { ГСО } 8916-2007, \\
\text { № }{ }^{\circ} 3057, \\
22.04 .2018\end{array}$ & $\begin{array}{c}\text { ГСО } 9447-2009 \text {, } \\
\text { № } 4036, \\
04.12 .2019\end{array}$ \\
\hline The range of absorbed doses, $k G y$ & $5 \ldots 50$ & $5 \ldots 150$ & $30 \ldots 200$ & $1 \ldots 10$ & $0.05 \ldots 10$ \\
\hline The range of the absorbed dose rate, $\mathrm{Gy} \cdot \mathrm{s}^{-1}$ & $10^{-1} \ldots 10^{5}$ & $10^{-1} \ldots 10^{5}$ & $10^{-1} \ldots 10^{5}$ & $10^{-1} \ldots 10^{5}$ & $10^{-3} \ldots 10^{3}$ \\
\hline \multicolumn{6}{|l|}{ The range of radiation energy, $\mathrm{MeV}$} \\
\hline for photon radiation & $0.66 ; 1.25$ & $0.66 ; 1.25$ & $0.66 ; 1.25$ & $0.66 ; 1.25$ & $0.66 ; 1.25$ \\
\hline for electron radiation & $0.3 \ldots 10$ & $0.3 \ldots 10$ & $0.3 \ldots 10$ & $0.3 \ldots 10$ & - \\
\hline $\begin{array}{l}\text { The boundaries of permissible } \\
\text { values of fractional error of appraisal } \\
\text { values of validation at } \mathrm{P}=0.95 \%\end{array}$ & 7 & 3 & 7 & 7 & $\begin{array}{c}5 \\
\text { (50 - } 500 \text { Gy) } \\
7 \\
(1-10 \mathrm{kGy})\end{array}$ \\
\hline $\begin{array}{l}\text { Fractional error of measurement of } \\
\text { absorbed dose at } \mathrm{P}=0.95 \text {, not more, } \%\end{array}$ & 12 & 7 & 15 & 15 & $\begin{array}{c}10 \\
\text { (50 - } 500 \text { Gy) } \\
15 \\
(1-10 \text { kGy) }\end{array}$ \\
\hline The temperature during irradiation, ${ }^{\circ} \mathrm{C}$ & $15 \ldots 40$ & $15 \ldots 40$ & $15 \ldots 40$ & $15 \ldots 40$ & $15 \ldots 40$ \\
\hline Registering of optical density after irradiation & $\begin{array}{l}\text { from } 30 \text { minutes } \\
\text { to } 4 \text { days }\end{array}$ & $\begin{array}{l}\text { from } 30 \text { minutes } \\
\text { to } 4 \text { days }\end{array}$ & $\begin{array}{l}\text { from } 30 \text { minutes } \\
\text { to } 4 \text { days }\end{array}$ & $\begin{array}{l}\text { from } 30 \text { minutes } \\
\text { to } 4 \text { days }\end{array}$ & $\begin{array}{l}\text { after } 22 \text { - } 26 \\
\text { hours }\end{array}$ \\
\hline
\end{tabular}

Currently, to meet requirements of industry, which uses radiation technologies, of current importance is to provide a simple, stable and reliable for mass use film chemical detector for both low dose range of 0.5 to $10 \mathrm{kGy}$ and large doses-from 100 to $300 \mathrm{kGy}$ with high demands on measurement uncertainty (5 - 15)\%. Radiochromic sensitive composition based on azo dye dietilaminoazobenzol 4 is already established for manufacturing thin-film chemical detector in the range of 0.5 to $10 \mathrm{kGy}$; industrial irrigation technology of radiation-sensitive layer on a continuously moving belt with simultaneous drying is developed. All the necessary documentation for registration as a standard sample detector of absorbed dose is prepared. Similar developments are carried out for the range of large doses-(30 - 300) kGy.

The introduction of modern measuring technologies in industrial radiation processes helps to ensure safety of the produce, the required level of the production increase, to solve environmental issues, as well as increase the level of metrological support of key fields of science, engineering and technology (energy, electronics, technology and production, including nanotechnology, environment, medicine, etc.).

\section{References}

[1] Generalova, V.V., Gursky, M.N., Gromov, A.A., Janjora, A.P. and Sysak, A.E. (2008) Role of Standards in Ensuring Reliability and Traceability of Absorbed Doses of Ionizing Radiation in Radiation Technologies. Proceedings of the 35th International Seminar on No Radiation and Space Materials Science of the FSUE NIFHI, Obninsk, 7-9 October 2008.

[2] Generalova, V.V., Gursky, M.N., Gromov, A.A. and Sysak, A.E. (2011) Role of Standards in Ensuring Reliability and Traceability of Absorbed Doses of Ionizing Radiation in Radiation Technologies. Proceedings of the 3rd All-Russia Scientific-Technical Conference with International Participation "Standards in Measuring and Technologies", FSUE UNIIM, Ekaterinburg, 12-17 September 2011.

[3] Generalova, V.V. (2009) Role of Metrology and Standardization during Radiation Sterilization of Medical Items. Scientific-Technical Conference "Discussion of 'Technical Order of Safety of Medical Items' for Single-Use Items” of the 7th International Trade-Show “Laboratory Ekspo 2009”, Moscow, 10 November 2009.

[4] Generalova, V.V. and Janjora, A.P. (2012) Validation of the Radio Sterilization of Single-Use Medical Items 
медицинских изделий. Moscow Metrological Forum “Metrology-2012”, the 4th Moscow International Symposium “Accuracy. Quality. Safety”, Moscow, 23-25 May 2012.

[5] Generalova, V.V. (2007) To the Subject of Radiation Processing Foodstuffs, Spices, Drugs and Auxiliary Materials. Medical Card Index, 5. 